\title{
合成吸収糸による頸部皮膚縫合法
}

\author{
鈴木 慎二 ${ }^{1)} \cdot$ 庄司 和彦 ${ }^{1)} \cdot$ 高北 晋一2) $\cdot$ 池上 聰1) \\ 河田 恭孝3) ・ 丸毛みゆき1) ・ 岸本曜1) ・ 児嶋 剛1)

\section{Synthetic Absorbable Suture for the Neck Skin Closure}

\author{
Shinji Suzuki, Kazuhiko Shoji, Satoshi Ikegami, Miyuki Marumo, \\ Yo Kishimoto and Tsuyoshi Kojima \\ (Tenri Hospital) \\ Shinichi Takagita \\ (Kyoto National Hospital) \\ Yasutaka Kawata \\ (Shizuoka General Hospital)
}

\begin{abstract}
In neck surgery, the exposed scars of the primary suture should be fine for favorable cosmetic results. We previously used subcuticular and epithelial nylon sutures, but recently we have been using monofilament synthetic absorbable sutures (Polydioxanone; PDS-II ${ }^{\circledR}$ ) in subcuticular closure to avoid indurations beneath the skin and late foreign body reactions. The scars of surgical incisions closed with PDS-II ${ }^{\circledR}$ were not inferior to those with nylon sutures, and we report below.

In the prevention of hypertrophic scars, providing tensile relief and eliminating level differences of the skin are most important. The tensile strength of PDS-II ${ }^{\circledR}$ is retained for about 2 months, which is not long enough. Thus, subcuticular PDS-II ${ }^{\circledR}$ sutures require sufficient eversion to reduce scar stretching by providing dermal support for longer terms. We call this technique "hypereversion". This technique does not require the control of degree of eversion according to patient age, and allows uniform sutures.

Moreover, to get fine scars without suture marks, we are using film dressing (Op-site $\left.{ }^{\circledR}\right)$ for wound fixation instead of epithelial suture in the early post operative period. When epithelial suturing is eliminated, level differences of the skin must be avoided in the subcuticular closure.
\end{abstract}

Key words : neck surgery, PDS-II ${ }^{\circledR}$, hypereversion

はじめに

頸部は露出しているため, 頸部手術においては手術瘏 痕ができるだけ目立たないように配虑することが望まれ

る. 肥厚性瘢痕を防止するためには, 真皮埋没縫合によ る創面の減張が最も重要である. 埋没縫合には通常非吸 収糸が使用されるが，埋没縫合糸は瘢痕の成長が止まる
までの数カ月は縫合部を減張する必要があるものの，そ のあとは不要であり，そのまま放置すれば生体にとって 異物となる ${ }^{1)}$. 当科でも以前はナイロン糸で真皮埋没縫 合を行っていたが, 術後しばらくして特に真皮の薄い人 の場合は皮下結節が目立ってくる例（図 1）や，体内に 異物として残るため異物反応を起こして徐々に排泄さ

1）天理よろづ相談所病院耳鼻咽喉科

2) 国立京都病院耳鼻咽喉科

3）静岡県立総合病院耳鼻咽喉科 


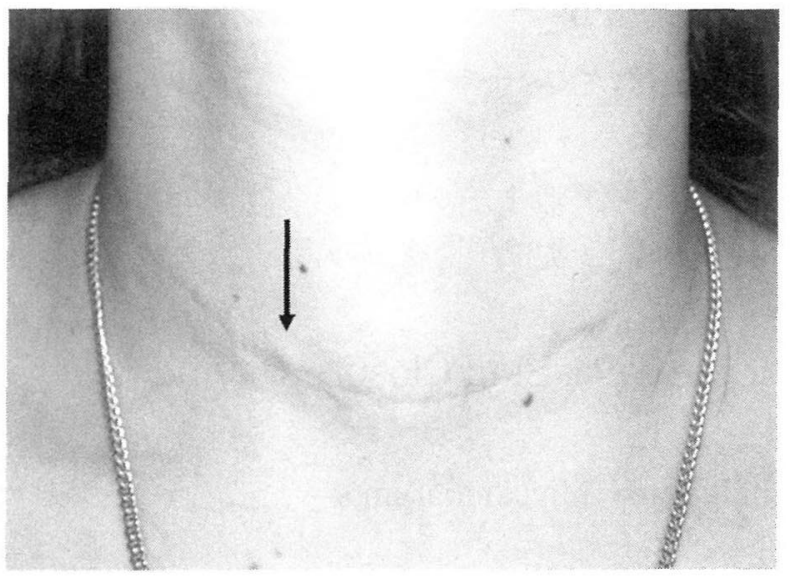

図 1 皮下結節例（29 歳女性, バセドウ病術後 1 年） 皮下結節矢印で示す.

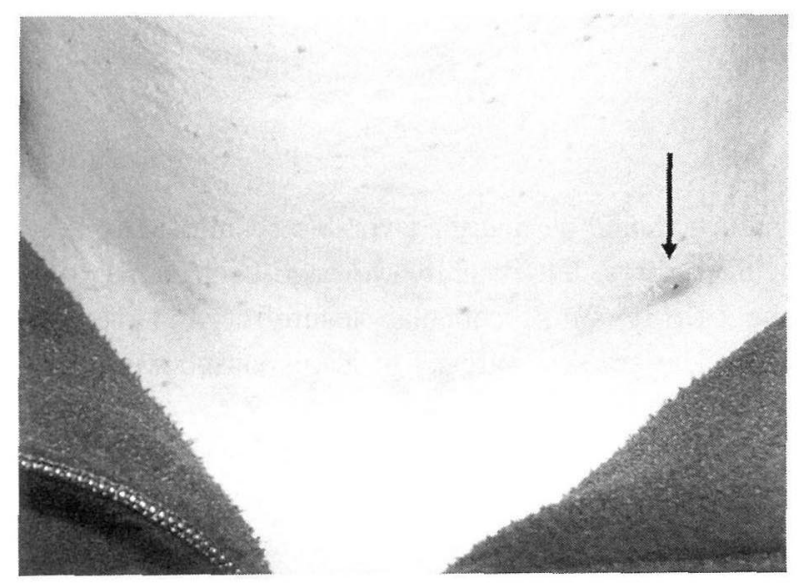

図 2 異物反応例 (26 歳女性, バセドウ病術後 9 カ月) ナイロン糸の晎物反応により排出されようとしている (矢印).

れてくる例（図 2) もある。そこで，最近われわれは ETHICON 社より開発されジョンソン・エンド・ジョン ソン社より販売されている PDS-II ${ }^{\circledR}$ といらモノフィラン トの吸収性縫合糸を用いている. PDS-II ${ }^{\circledR} の$ 材質はポリ ディオキサノンといら合成糸であり，ナイロン糸と同等 に組織反応が少なくなっている ${ }^{1)}$. $\mathrm{PDS}^{\circledR}$ として市販され た当初は，硬すぎて披いにくい欠点があった，この欠点 を改善すべく，系表面を加熱溶解して表面付近の結晶性

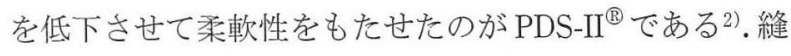
合創の治癒過程において創縁にかかる張力が深くかか わっているが, PDS-II ${ }^{\circledR}$ は吸収糸のなかでは抗張力保持 期間唯約 2 力月と比較的長い3. 生体内に埋没後は加水分
解により炭酸ガスと水に分解されて, 徐々に吸収され 6 〜 7カ月で完全に体内から消失する4).

以下にPDS-II ${ }^{\circledR}$ を用いた真皮埋没縫合の手法とその結 果を報告する。

\section{方法}

縫合部のコラーダンが最大量に達するのに 6 週間以上 かかり5)，コラーダンの総量は $6 \sim 12$ 週間まで増大し続 ける6)ことから，疲痕の開大をなくすための抗張力保持 期間として $2 \sim 4$ 月は必要といわれているが, PDS-II ${ }^{\circledR}$ は2力月位で十分に長いとはいえない，そこでわれわれ は縫合時の工夫として可能な限り高く創面を盛り上げ て，創縁に張力がかかりにくいようにしている。この方 法を，われわれは“hypereversion”と呼んでいる.

非吸収系で真皮埋没縫合を行ら場合, 高齢者では皮膚 の緊張が少なく eversionを行うと盛り上がりが残るため eversion は不要である (図 $3 a$ ). 逆に, 若年者では eversion が必要だが，症例に応じて盛り上げる度合いを調節しな ければならず，その判断が難しい（図 3 b). それに比べ て, 吸収系で真皮埋没縫合を行う場合は年齢にかかわら ず同じ手技で縫合すればよいと考えている(図 $3 \mathrm{c}$ ).

縫合手技の実際を図 4 に示す，広頸筋の縫合と真皮縫 合を別々に行う方法と同時に行う方法があるが，まず前 者について解説する.

広頸筋のみを同じ PDS-II ${ }^{\circledR}$ で縫合した後, 広頸筋の浅 側で創縁の上皮より $10 \sim 15 \mathrm{~mm}$ 離れた皮下脂肪層から 針を刺入して，創縁の上皮より $4 \mathrm{~mm}$ 離れたところで針 を出す (図 $4 \mathrm{a}$ )。このとき，皮膚の挫滅を起こさないよ うわれわれは藤森のフックピンセットを用いている. 創 縁から 5〜 $10 \mathrm{~mm}$ のところで指腹で針の位置を感じなが ら系と上皮の距離が最も短くなるようにする (図 4 b). 結 ぶ前に糸に力をかけて引くと，創の両サイドにくぼみが できて創面が盛り上がる（図4c). 図 $4 \mathrm{~d}$ は一部縫合が終 了したところである。“ムカデの足”状の糸痕（suture mark）を残さないために，われわれは表皮縫合をせずに 透明のフィルムドレッシングを貼って創の固定を行って いる(図 $4 \mathrm{e})$.

また，広頸筋の縫合と真皮縫合を同時に行う場合は， 広頸筋の裏面より針を刺入して, 創縁から $10 \mathrm{~mm}$ のとこ ろが最も系と上皮の距離が短くなるようにして，創縁か ら $4 \mathrm{~mm}$ のところで針を出せばよい. 
a
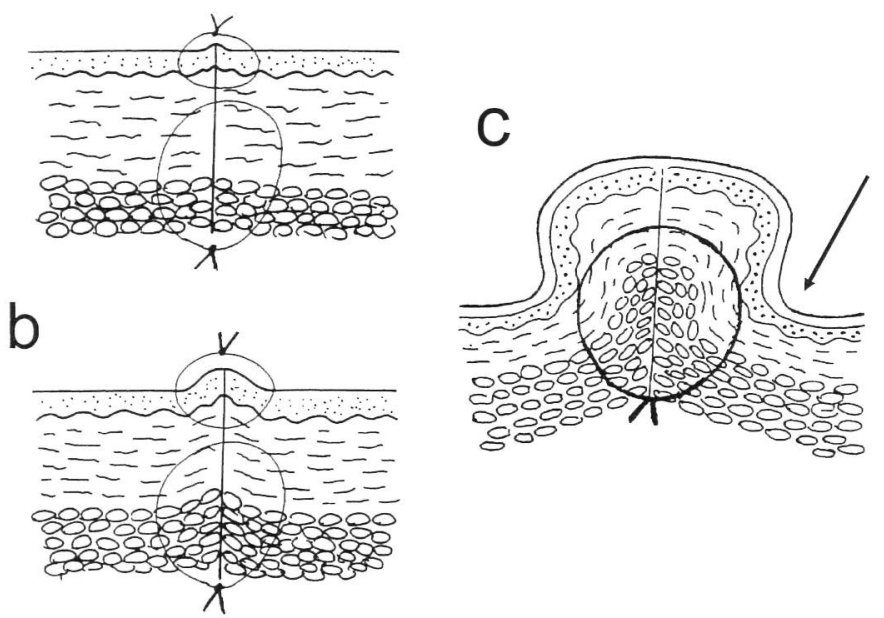

図 3 非吸収系（a. 高齢者，b. 若年者）と吸収系（c. hypereversion）による縫合法の違い 矢印はフィルムドレッシングを示す.

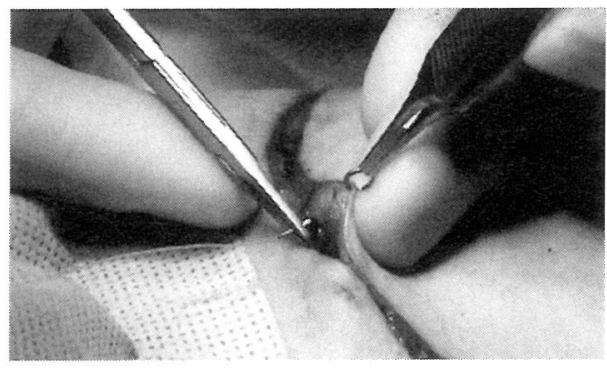

a

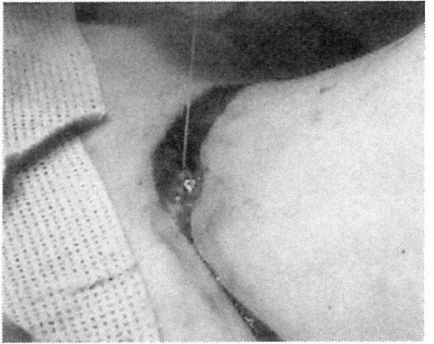

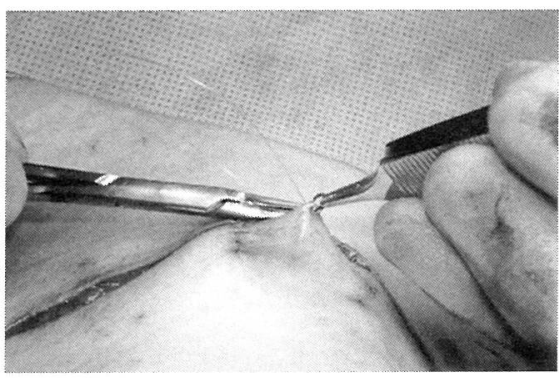

b

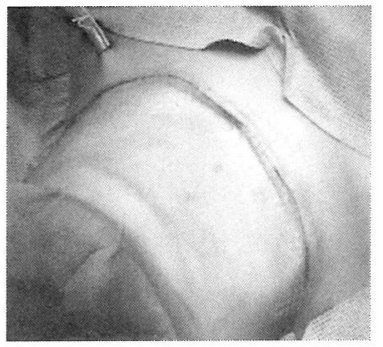

図 4 PDS-II ${ }^{\circledR}$ を用いた真皮埋没縫合の手技

\section{結 果}

Ray ら 7)のポリディオキサノン糸に関する動物実験で は，埋没後 2 週で $74 \% ， 4$ 週で $58 \% ， 6$ 週で $41 \% ， 8$ 週 で 14\%と抗張力が徐々に弱まっていき，6力月で完全に 吸収された。
われわれの症例で “hypereversion” を行った創面は, 視診上術後 1カ月では術直後とほとんど変わらない状態 であったが，3カ月位で盛り上がりがなくなり，4カ月後 には平坦になっていた。図 5 に症例を示すが，こ扎は一 部瘢痕が肥厚した例であり，おそらく創面の段差が原因 


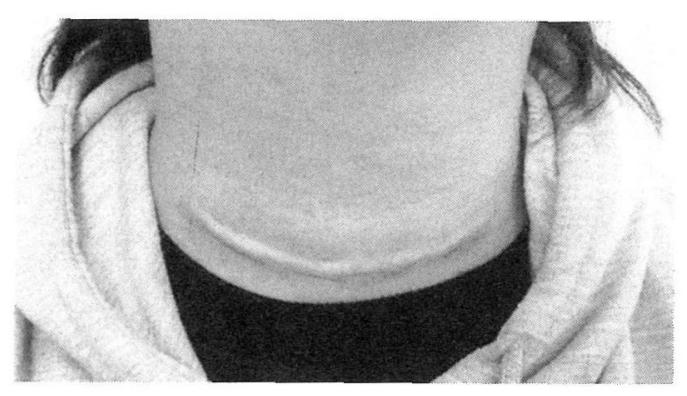

1力月後

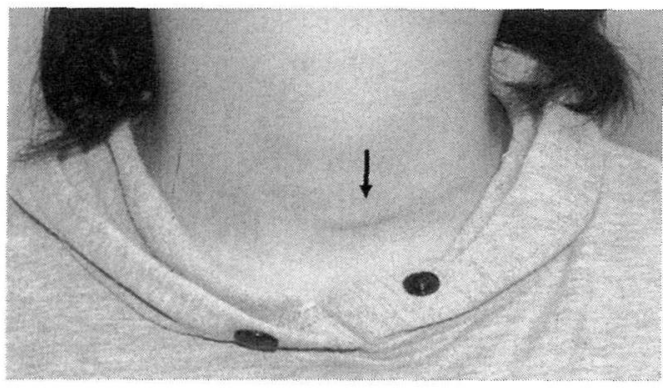

5 力月後

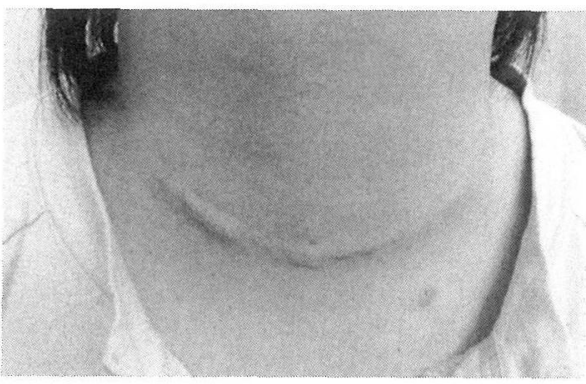

3 力月後

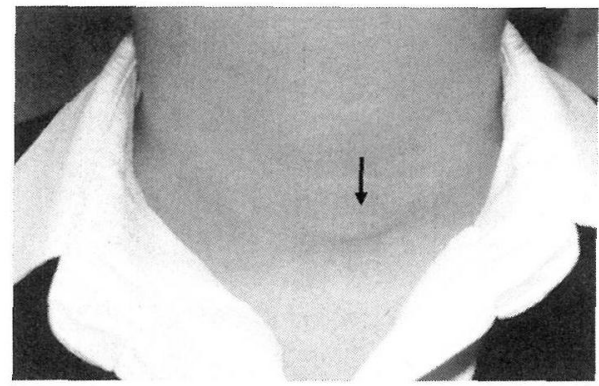

7 力月後

図 5 一部瘏痕肥厚例（19 歳女性, バセドウ病例） 肥厚した瘢痕を矢印で示す。

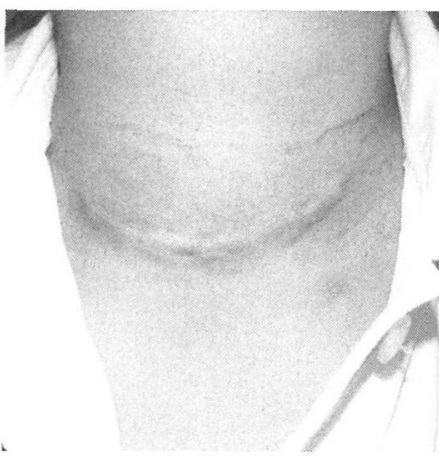

1力月後

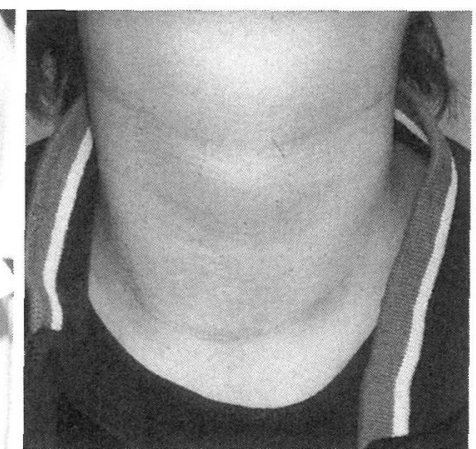

4カ月後

図 6 治癒良好例（17 歳女性，バセドウ病例）

と思われた。このことから，表皮縫合を行わない場合は 段差を作らないように正確な埋没縫合を行うことが重要 である. 図 6 亿治癒良好例の 1 例を示すと, 17 歳と若年 者であるが創はほとんど目立たない状態になっている。

当科で頸部手術を行った症例において, 年齢 40 歳未満 で術後 6 カ月以上経過観察できた症例について, 瘢痕治 疻良好例と瘏痕肥厚例の割合を年齢別にグラフに表した (図 7)。一時瘢痕肥厚例とは, 術後 $1 \sim 2$ 力月の早期には
創が赤く腫れていたが半年〜 1 年位で徐々に目立たなく なった例を示している。ここで図 5 に示した症例のよう に大方良好に治癒していても創面の段差のために一部瘢 痕が肥厚した例も瘷痕肥厚例に含めた。まず，2000 年 1 月〜 2001 年 12 月の 2 年間に当科でナイロン糸を用いて 真皮埋没縫合を行った計 43 例を A 群とした. A 群の年 齢は $12 \sim 39$ 歳, 性別は男性 8 例, 女性 35 例, 原疾患は バセドウ病 12 例・甲状腺腫瘍 23 例・耳下腺腫瘍 4 例 · 


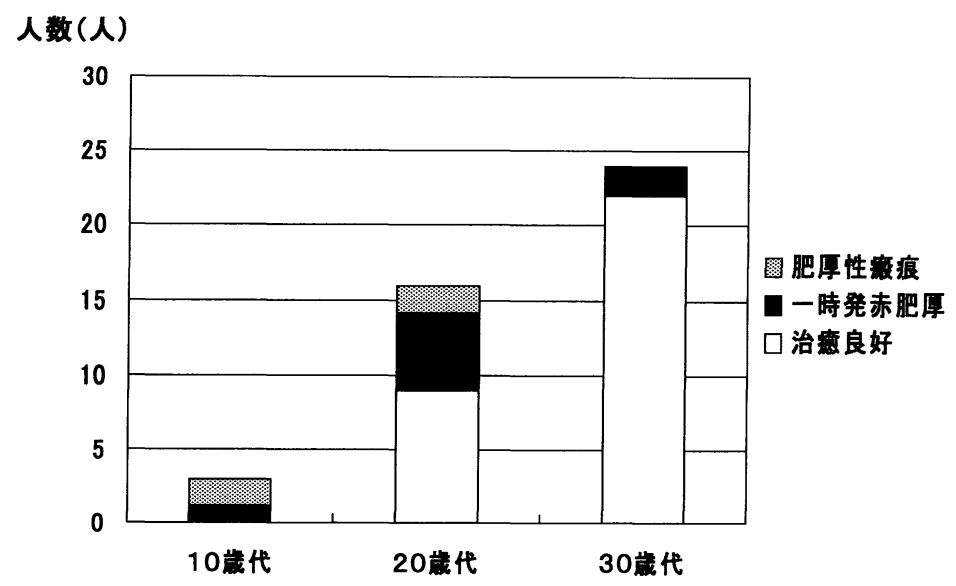

A：ナイロン糸による縫合

\section{人数(人)}

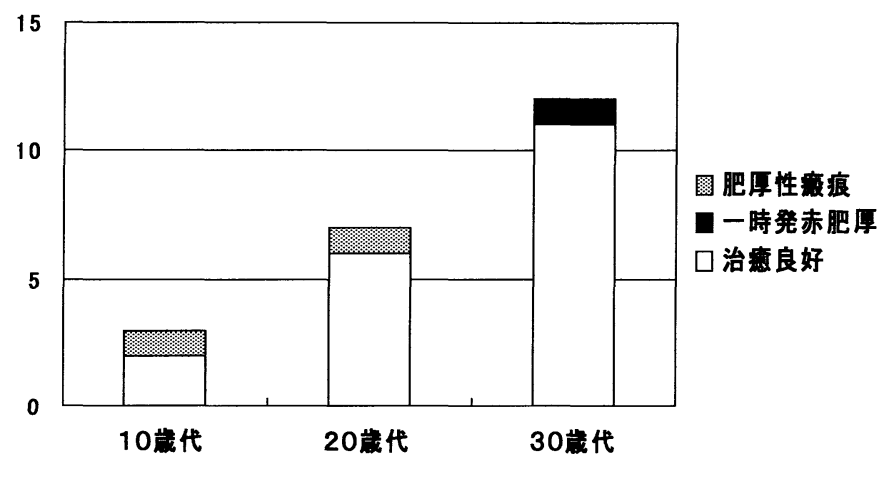

B：モノフィラメント吸収系による縫合

図 7 年齢と創治癒状態の関係

顎下腺腫瘍 3 例・正中頸囊胞 1 例であった. A 群に関し ては，10 代や 20 代の若年者で般痕が目立つ例が多かっ た. 次に, 2002 年 1 月 2002 年 12 月の 1 年間に吸収糸 を用いて “hypereversion”による手法で真皮埋没縫合を 行った計 22 例を B 群とした. B 群の年齢は $17 \sim 39$ 歳, 性別は男性 2 例・女性 20 例, 原疾患はバセドウ病 7 例 · 甲状腺腫瘍 9 例 - 耳下腺腫瘍 4 例 - 顎下腺腫瘍 1 例・正 中頸囊胞 1 例であった. B 群に関しては, 統計学的有意 差は認めなかった（フィッシャー直接検定）ものの, 10 代や 20 代の若年者でも良好に治癒している例が多くみら れた。 なお，PDS-II ${ }^{\circledR}$ の材質に起因すると思われる副作 用は認められず，高齢者で術後 6 力月以降に eversion が 残存した例はなかった。

\section{考 察}

術創を美しくするためには, 術創の位置や長さに加え,
(1) “ムカデの足” 状の糸痕を残さないことと，(2)肥厚性 瘢痕の防止がポイントになる。(1)については，表皮縫合 を行わないことが根本的な解決策である。しかし，術後 の安静が保ちにくい頸部では表皮縫合を行わない場合, 外力から傷を守る意味で創縁を固定するための何らかの 手段が必要である．縫合部にフィブリン糊を注入した後 に外科用絆創膏で固定する方法8) むあるが，最近では防 水性ドレッシングの機能も有している合成皮膚表面接着 剤が広まっており，真皮埋没縫合を行った後にこれを用 いて創固定を行う方法もある ${ }^{910)}$. われわれは, 吸収系 による真皮埋没縫合を開始した同時期からフィルムド レッシング材（商品名：Op-site ${ }^{\circledR}$ IV3000）を用いた創固 定とドレッシングを行っている.この Op-site ${ }^{\circledR}$ IV3000 は その名前が示すとおり, 中心静脈カテーテルの刺入部に 対するドレッシング材として作られたものであるが，透 明のポリウレタンフィルムからできた半閉鎖性ドレッシ 
ング材で, 防水性であると同時に創面からガスと水蒸気 の透過を許す機能がある.そのため, 汗をかいてむドレッ シングの浮きは起こりにくく, 当科では術後 5 日目にフィ ルムを剥がしているが，それまでの間の貼り換えは不要 で, 創固定の役割を十分に果たしていると思われる，ま た, 術直後からのシャワーや入浴に対しても患者の不安 は少なく, 術後の QOL 向上に役立っている.

(2)の肥厚性誐痕の防止に関しては，皮膚の段差をなく して raw surfaceを作らないことと創面の減張が最重要で ある. 皮膚の段差をなくすために表皮縫合はある意味有 用であるが，皮膚接着㓮やフィルムドレッシングでは段 差の修正はできないため，現在われわれは真皮縫合の際 に極力段差を作らないように心掛けている．また，創面 の減張に関しては非吸収糸の方が吸収糸より優れている ため, 当初われわれは瘢痕の治癒状態に関して非吸収 糸に近い成績であればよいと考えていた。非吸収系 と吸収糸の比較検討を行うにあたり, 創縁に緊張のか かりやすい若年者に注目したが, 結果は吸収糸でも “hypereversion”の手法を用いれば非吸収糸に劣らないこ とがわかった。 また，高齢者においても eversion は残存 せず, 高齢者で “hypereversion”による縫合を行っても問 題はないと思われる.

術後のテープ固定に関して “hypereversion”による縫 合創は 3カ月ぐらいまでは創の減張がはかられているた め, われわれは安静固定のためのテーピングは不要と考 えている. しかし, 遮光目的以外に術直後はむしろ創の 盛り上がりが目立つため, できればきれいになるまで隠 したいという患者側の希望で創面にテープを貼っている 例がある.今後は引き続き同じ手法で皮膚縫合を行い, さらに症例を増やしていく予定である.

\section{まとめ}

モノフィラメント吸収糸を用いた “hypereversion” に よる頸部皮膚縫合の手技および臨床成績を報告した。

1）非吸収糸を用いた場合と異なり,年齢にかかわらず 同一の手技で縫合すればよい.
2）表皮縫合を行わない場合, 美しい䑤痕にするために は創縁の段差を作らないよう心掛ける必要があると思わ れた.

3）瘢痕の治癒状態に関して, 非吸収糸の場合と比べて も劣ることはなかった.

なお, 本論文の要旨は第 65 回耳鼻咽喉科臨床学会（平成 15 年 7 月 4 日, 京都市）にて口演した.

\section{参考文献}

1）橋本一郎, 中西秀樹, 長江浩郎, 他 : 合成吸収性縫合糸 polydioxanone (PDS-II $\left.{ }^{\circledR}\right)$ とナイロン糸の鼠径部採皮創にお ける術後洀痕の比較検討. 形成外科 $43: 713 \sim 717,2000$.

2）富畑賢司：最近の生体吸収性縫合系の動向. 生体材料 19 : $143 \sim 147,2001$.

3）園田仁志：縫合糸, 針付き縫合糸, 縫合材料の種類と使い 分け. 臨外 $53: 14 \sim 18,1998$.

4）福田 修, 上田和毅, 桜井 淳, 他: 新合成吸収性綘合系· Polidioxanone の使用経験. 基礎と臨床 18:352 359, 1984.

5）福田 修: 皮虐縫合. 外科 Mook No. 4. 縫合と吻合（福田 修編). $15 \sim 32$ 頁, 金原出版, 東京, 1978 .

6）島津研三, 芝 英一, 東村昌代, 他：目立たない旅痕にす るための方法. 内分泌外科 $17: 27 \sim 31,2000$.

7) Ray JA, Doddi N, Regula D, et al. : Polydioxanone (PDS), a novel monofilament synthetic absorbable suture. Surg Gynecol Obstet $153: 497 \sim 507,1981$.

8）庄司和彦, 福島英行, 児嶋久剛, 他 : Tisseel ${ }^{\circledR}$ の甲状腺手 術での使用経験. 耳鼻臨床 $83: 337 \sim 341,1990$.

9）九冨五郎, 大村東生, 八十島孝博, 他: 乳腺および甲状腺 手術に対する DERMABOND ${ }^{\circledR}$ の使用経験. 臨床と研究 78: $776 \sim 778,2001$.

10）柳内良之, 八十島孝博, 秦 史壮, 他: 外来手術および手 術後早期退院に向けての DERMABOND ${ }^{\circledR}$ の使用経験. 臨床 と研究 $79: 869 \sim 872,2002$.

原稿受付: 平成15年 7 月 25 日 原稿採択：平成15年10月 1 日 別刷請求先：鈴木慎二 テ632-8552 天理市三島町200 天理よろづ相談所病院耳鼻咽喉科 